\title{
A new species of the genus Odocnemis Allard, 1876 (Coleoptera: Tenebrionidae) from Greece
}

\section{Новый виА рода Odocnemis Allard, 1876 (Coleoptera: Tenebrionidae) из Греции}

\author{
M.V. Nabozhenko ${ }^{1,2}$, S.V. Nabozhenko ${ }^{1}$ \\ M.В. Набоженко ${ }^{1,2}$, С.В. Набоженко ${ }^{1}$
}

\begin{abstract}
Institute of Arid Zones, Russian Academy of Sciences, Chekhov str., 41, Rostov-on-Don 344006 Russia. E-mail: nalassus@mail.ru ${ }^{2}$ Southern Federal University, Bol'shaya Sadovaya str., 105, Rostov-on-Don 344006 Russia
\end{abstract}

${ }^{1}$ Институт аридных зон ЮНЦ РАН, пр. Чехова, 41, Ростов-на-Аону 344006 Россия

${ }^{2}$ Южный федеральный университет, ум. Большая Садовая, 105, Ростов-на-Аону 344006 Россия

Key words: Coleoptera, Tenebrionidae, Helopini, Odocnemis, new species, Greece. Ключевые слова: Coleoptera, Tenebrionidae, Helopini, Odocnemis, новый виА, Греция.

Abstract. A new species Odocnemis bekiri sp. n. is described from Greece (Macedonia Province). The species belongs to the tuberculiger species-group and differs from similar and all other species of the genus in the completely pubescence body.

Резюме. Описан новый виА Odocnemis bekiri sp. n. из Греции (провинция Македония). ВиА относится к группе видов tuberculiger и отмичается от похожих и всех остальных видов рода полностью опушенным телом.

The genus Odocnemis Allard, 1876 was revised by Reitter [1922]. Since that time only some taxonomic works on Mediterranean species of the genus had been published [Keskin, Nabozhenko, 2011; Nabozhenko, Keskin, 2013]. Below we describe a new species of Odocnemis from Greece (Lekanis Mountains) which belongs to the tuberculiger species-group. Species of this group (eastern Mediterranean O. tuberculiger (Reiche et Saulcy, 1857), O. badius (Redtenbacher, 1849), O. nigropiceus (Küster 1850), O. crenatostriatus (Allard, 1877), O. alcides (Reitter, 1922), O. cretensis (Seidlitz, 1896) and O. intricatus (Allard, 1876)) have the following diagnostic characters: epipleura flattened from base to sutural angle, their inner small carina reaching the sutural angle; dorsal epipleural carina reaching apex of elytra, where transformed to elongate horizontal platform; wings absent; inner side of femora smooth, without punctation. The most diversity of this group is observed in Greece and surrounding countries.

\section{Odocnemis bekiri sp. $\mathbf{n}$.}

(Figs 1-8)

Material. Holotype, ỡ : Greece, Propotsani, 22.05.2004 (leg. L. Adám). Paratype: 1 , , Greece, Macedonia, Lekanis Mt., 10 km NE Nikiforos, swept and singled, 11.05.2009 (leg. A. Kotán, A. Márkus and T. Németh). Holotype and paratype are deposited in Hungarian Natural History Museum (HNHM, Budapest, Hungary).

Description. Male. Body length $11 \mathrm{~mm}$, width $2.6 \mathrm{~mm}$ Body slender, shine, brown with reddish brown legs, completely pubescent with recumbent hairs. Eyes large, convex. Head width 1.7 times width of interocular space. Anterior margin of frontoclypeus straight. Genae strongly oblique forward and strongly rounded in middle. Lateral margin of head between genae and frontoclypeus without emargination. Frontoclypeus strongly depressed. Punctation of head coarse and dense (puncture diameter 2 times as long as distance between punctures); punctures large, round and deep. Antennae long and thin, their 4 apical antennomeres extending beyond base of pronotum almost reaching half of elytral length. All antennomeres longitudinal.

Pronotum almost with subequal length and width (only 1.05 times as wide as long, widest before middle, weakly cordiform, 1.35 times as wide as head. Lateral margins of pronotum weakly rounded and weakly sinuated basally. Anterior margin of pronotum widely rounded in middle and emarginated laterally; base widely weakly rounded. Anterior angles acute, distinct (anterior view), posterior angles almost right. All margins of pronotum finely beaded. Disc of pronotum regularly weakly convex; punctation of disc coarse and dense as on head, punctures round, deep. Prothoracic hypomera with longitudinal wrinkles. Prosternal process obtuse conical.

Elytra elongate ellipsoid shape, almost acute apically, 1.78 times as long as wide, widest at middle, 1.77 times as wide as head, 1.3 times as wide and 2.45 times as long as pronotum. Strial punctures elongate, connected with deep furrows. Interstriae convex, with coarse, not dense punctation (puncture diameter subequal to distance between punctures), punctures deep, round. Each interstria with not more than 2 punctures in transverse section. Epipleura and epipleural carina reaching elytral apex. Pubescence of interstriae consists of long bent recumbent hairs. Interstriae in apical third of elytra with sparse distinct tubercles.

Meso- and metaventrite, mesepimera and metepisterna with coarse punctation as pronotum and head. Abdominal ventrite 1 flattened in middle, with denser and finer punctation and denser pubescence; abdominal ventrite 5 with same but sparser punctation, not beaded apically.

Protrochanters with several hairs and 1 long sensillum; mesoand metatrochanters only with 1 long sensillum. Protibiae with 3 large teeth in middle of inner side; mesotibiae with 3 small teeth in apical half of inner side; metatibiae without theeth.

Female. Body length $7.8 \mathrm{~mm}$, width $2.9 \mathrm{~mm}$. Body more robust. Antennae shorter, with only 3 apical antennomeres extending beyond base of pronotum. Head completely pubescent, 

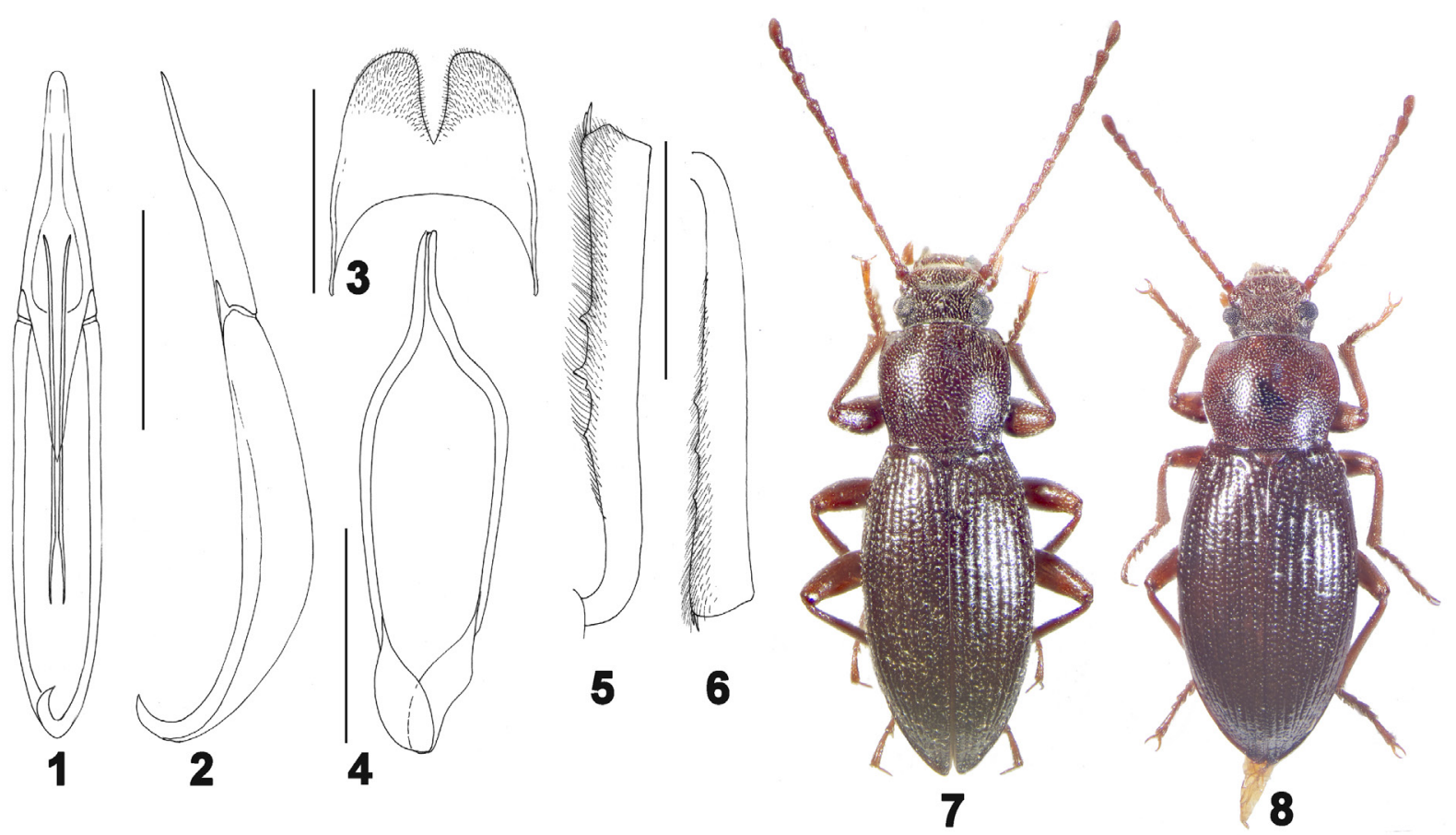

Figs 1-8. Odocnemis bekiri sp. n.

1 - aedeagus ventrally; 2 - aedeagus laterally; 3 - male inner sternite VIII; 4 - gastral spicula; 5 - male protibia; 6 - male mesotibia; 7 - male, general view; 8 - female, general view. Scale bars $1 \mathrm{~mm}$.

Рис. 1-8. Odocnemis bekiri sp. n.

1 - эдеагус вентрально; 2 - эдеагус латерально; 3 - VIII внутренний стернит самца; 4 - гастральная спикула; 5 - передняя голень самца; 6 среАняя голень самца; 7 - самец, общий виА; 8 - самка, общий виА. Масштабные кинейки 1 мм.

pronotum with short setation and lateral pubescence. Pronotum weakly transverse, 1.2 times as wide as long, 1.4 times as wide as head. Elytra pubescent with sparse recumbent hairs only in base and apical part. Elytra 1.7 times as long as wide, 1.87 times as wide as head, 1.3 times as wide and 2.67 times as long as pronotum. Tibiae without teeth.

Differential diagnosis. The new species differs from all known Odocnemis in the completely pubescence body.

Etymology. The species is named in honour of our friend and known Turkish coleopterologist Bekir Keskin (Ege University, Bornova - Izmir).

\section{Acknowledgements}

The authors are much obliged to Ottó Merkl (HNHM) for the providing material and to Vladimir Shmatko (Institute of Arid Zones of Southern Scientific Centre of
Russian Academy of Sciences, Rostov-on-Don, Russia) for the preparation of photographs.

The study was supported by the Russian Foundation for Basic Research 15-55-05099 for the first author.

\section{References}

Keskin B., Nabozhenko M.V. 2011. Review of the genus Odocnemis Allard, 1876: O. korbi species-group (Coleoptera: Tenebrionidae: Helopini). Annales Zoologici. 61(2): 339-354.

Nabozhenko M.V., Keskin B. 2013. Disjunctive distribution of Odocnemis protinus (Reitter, 1900), the first representative of the genus (Coleoptera: Tenebrionidae: Helopini) in Iran. Yug Rossii: ekologiya, razvitiye. 3: 66-72 (in Russian).

Reitter E. 1922. Bestimmungstabelle der palaearktischen Helopinae (Col. Tenebrionidae). Wiener Entomologische Zeitung. 39: 1-44, 113-171. 